\title{
Hoja Blanca Symptoms Not Observed on Susceptible Rice Varieties in Puerto Rico'
}

\author{
Enrique Ortiz-Torres, ${ }^{2}$ Thomas Theis, ${ }^{3}$ and Donald V. $\mathrm{McV}^{\mathrm{C}} \mathrm{y}^{2}$ \\ INTRODUCTION
}

"Hoja blanca", an insect-transmitted virus disease of rice, is a potential threat to rice production in Puerto Rico. This disease, characterized by a chlorosis of the leaves, is widespread in South and Central America and may reduce yields 75 percent. The rice varieties grown in Puerto Rico, and especially the most promising variety, Zenith, all are susceptible to the diseases. Both the insect vector (Sogata orizicola Muir) and a common weed, "arrocillo" (Echinochloa colonum Link), reported to carry a disease very similar to hoja blanca, are present in Puerto Rico $(1,2) .^{4}$

\section{PROCEDURE}

Plantings of three susceptible rice varieties: Zenith, Fortuna, and Japón, were made at three locations on the Island. These locations were the Lajas Valley, on the southwest corner of the Island; Corozal, in the central portion; and Gurabo, in the eastern section. Rice is grown commercially on a small scale in these areas, and the vector of hoja blanca virus is known to be present in the Corozal and Gurabo regions.

Blocks measuring $32 \times 32$ feet were planted at the three locations. In addition, experimental commercial plantings several acres in size in the Lajas Valley were studied. Observations were made over a 2-year period (1959-60) on both fall and spring plantings in the Lajas Valley and for 1 year, 1960, and at Corozal and Gurabo on fall plantings only. The observations were made every 2 weeks from the time the plants were 4 weeks old until harvest.

\section{RESULTS}

Although the plants were examined by men thoroughly familiar with hoja blanca, no symptoms of this disease were observed at any time in any of the plantings. Some chlorosis and leaf-drying were noted at the

${ }^{1}$ In cooperation with the Agricultural Experiment Station of the University of Puerto Rico, Río Piedras, P.R.

2 Agronomist and Plant Pathologist, respectively, Federal Experiment Station, CRD, USDA, Mayagüez, P.R.

${ }^{3}$ Formerly Plant Pathologist, Federal Experiment Station; now Chief, Tobacco and Sugar Crops Research Branch, CRD, USDA, Beltsville, Md.

- Italic numbers in parentheses refer to Literature Cited p. 238. 
various locations, but these were similar to the symptoms of a physiological disorder described by Perumal ( 3 ) and not related to hoja blanca.

A recent report (4) has been interpreted by some readers as indicating that hoja blanca has been found on oats in Puerto Rico. A personal communication from one of the authors, however, stated that this report referred to oat plantings in Colombia and not to plantings in Puerto Rico.

\section{SUMMARY}

Although "hoja blanca" is a widespread and destructive disease in ricegrowing areas of Latin America, including some of the nearby Caribbean islands, and, although the insect vector is known to be present in Puerto Rico, no symptoms of this disease were observed in experimental rice plantings at three locations here. Up to the present there is no evidence that this disease is present in Puerto Rico, either on rice or on other host species.

\section{RESUMEN}

Aunque la grave enfermedad del arroz llamada "hoja blanca" está diseminada por todas las áreas arroceras de la América Latina, incluyendo algunas de las islas más cercanas a la nuestra y aunque se sabe que en Puerto Rico se encuentra el insecto vector, no se observaron síntomas de esta enfermedad en tres pruebas experimentales con arroz que se llevaron a cabo en tres distintos sitios de la Isla. Por lo tanto y hasta el presente no hay evidencia alguna de que tengamos esta enfermedad en Puerto Rico, ni en al arroz ni en otras especies susceptibles de hospedarla.

\section{LITERATURE CITED}

1. Kramer, J. P., and Murtorell, L. F., First records for the rice plant hopper, Sogata orizicola Muir, in Puerto Rico (Homoptera: Delphacidae), J. Agr. Univ. P.R. 44(4) 163-5, 1960.

2. Jennings, P. R., and Beachell, H. M., Hoja blanca disease of rice found in Mexico, Plant Dis. Rptr. 44(9) 751, 1960.

3. Perumal, S., Leaf-tip-drying discase on rice (Oriza saliva), Soil Sci. 91 218-21, 1960.

4. Gibler, J. W., Jennings, P. R., and Krull, C. F., Natural occurrence of hoja blanca on wheat and oats, Plant Dis. Rptr. 45 (5) 334, 1961. 